\title{
Roles of Democratic Volunteers in Developing Political Literacy
}

\author{
${ }^{1}$ AL RAFNI, ${ }^{2}$ SURYANEF \\ 1,2 Fakultas Ilmu Sosial, Universitas Negeri Padang, Jl. Prof. Dr. Hamka Air Tawar Padang 25131 \\ email: ${ }^{1}$ alrafni12@gmail.com; ${ }^{2}$ suryanef@gmail.com
}

\begin{abstract}
One of priorities on political development post- reformation movement is improving civic political literacy. The meaning of the literacy has been broadened. It is not merely related to exclusive political knowledge, but also refers to promote the effectiveness and participation of civic in daily basis political movement. This paper describes the role of democratic volunteers as facilitators of political education or community basedvoters education in previous general election in 2014. Further, the paper is also aimed at describing the roles of the democratic volunteers in implementing public political education and conducting other efforts in developing civic political literacy.
\end{abstract}

Keywords: democratic volunteer, political literacy, political movement

\section{Introduction}

Democratic volunteer is regarded as a program launched by the Comission of General Election responsible for conducting politics education or education for voters in a particular community. The program is further aimed at expanding public political participation and improving public faith toward the democratic process. It also involves the public role as democratic pioneers in their own community with the expectation that the political literacy can be improved when the role, functions, and performance of the volunteers can be optimally performed.

The rationale of the program is the tendency of voters' declination, both quantitatively and qualitatively. The indication can be observed from the last four of national and provincial general elections in many areas in Indonesia. The decreasing number of voters can be seen in in national election in 1999 $(92 \%)$, in $2004(84 \%)$, in2009 (71\%), and in $2014(53,6 \%)$. The tendency also occurs on regional level. In Padang, West Sumatera it was calculated that the number of voters in legislative general election in 2004 was $70 \%$, the percentage was decreasing in presidential election, namely $64 \%$. Further, the percentage of the voters in governor election was getting smaller in 2005 , namely $52 \%$. Of qualitive aspects, there is a tendency occurs among the community that they were pragmatic in deciding their vote. Thus the democratic volunteers program greatly contributes in conducting political education with the aim to increase the voters' participation.

According to Ravitch $(2010$, ) the essential of democracy is educating the distinguished groups of community to peacefully argue their different opinion and achieving the objectives of democracy which enable them to live peacefully hand in hand. Political behavior of the community indicates low political awareness and mostly against the ethics of democratic attitude and behavior. Thus, a very early education for political awareness in a particular community is highly required.

Process of promoting the political values has been influenced by a particular interest power. It is indoctric, formalistic and sporadic. Therefore the existence of democratic volunteers will change the paradigm of political education, started from political material resources, the delivered methods and content adjusted for community condition, situation and interests. The change of the political paradigm is known as

Received: October 26, 2016, Revision: March 09, 2016, Accepted: May 19, 2017

Print ISSN: 0215-8175; Online ISSN: 2303-2499.

Accredited by DIKTI. SK Kemendikbud, No.040/P/2014, valid 18-02-2014 until 18-02-2019, Indexed by DOAJ 
transformative political education.

Transformative political education is regarded as political education built in by community awareness and facilitated by the community who becomes the agent of political changes. The materials, strategy and the media are selected pursuant to characteristic of a particular community. Further, H.A.R. Tilaar (2000) states that there some principles of transformative pedagogy, namely: (1) investigating of normative educational process; (2) educational process is individual process; (3) building individual identity; (4) transformative pedagogic is a communicative pedagogic; (6) future goal oriented; (7) respecting human rights; (8) proximate environment where human is born among the community; (9) inner development process; (10) outer development process; (11) the harmony of intrinsic and extrinsic power; (12) the educational process is meaning-giving process; (13) long life learning and; humanization process.

Mustafa Pembangy (2008) simplifies the general principles of transformative education into five tenets, namely: (1) critical awareness; (2) futuristic knowledge; (3) skills importance; (4) humanist values orientation; and (5) quality assurance. Therefore, it implies that the objective of transformative education is basic principles changes on learners. Based on the teaching and learning process, according to Jack Mezirowas quoted by Nurhady Sirimorok (2010) transformative teaching and learning is a process in which an individual changes his/her frame of reference that rational cognitive operation is not merely involved but also emotional operation like self-control, critical and autonomous.

Transformative political education is expected to give a change to individual learners in many ways, such as quality of thinking, social skills, independence skills, and community quality in politics. Idrus Affandi (2011), states that methodologically, politic education is viewed as a process of political consciousness, which is categorized as normative ethics values, rationales and dialogic understanding. As a comprehensive process, the material delivery is adjusted based a particular community. Each community possesses special characteristics in achieving their own political enlightenment and consciousness. The democratic volunteers in charged for delivering politics education or voters' education in women community will apply a particular approach. There are some particular strategies conducted, such as visiting women social clubs and politely demonstrate some political education. This strategy is informal, enjoyable, open, and friendly with the expectation that political consciousness of the importance of democratic life can be built. Meanwhile, those in charged for marginal community will join the fishermen, workers, and farmers to have dialogue related to the importance of election and help the people to make their democratic choices. The such transformative political education helps people to learn to know, understand and finally, participate in a general election.

Based on the discussed issues, the conducted study is aimed at finding out and describing the answers of the followings questions: (1) what are the roles of democratic volunteers as facilitators of politics education/community based voting education in general election in 2014? (2) What are the government efforts to develop citizen political literacy? These two questions are the part of a research entitled Developing Training Models of Democratic Volunteers as the Facilitators of Community based Politics Education (Study of Democratic Volunteers in 2014 General Election in Padang).

\section{Research methodology}

This article is a part of researchers' study in Produk Terapan scheme that funded by Ristekdikti under the title: Developing training model for democratic volunteers as political education facilitator based community. This study uses qualitative approach through focus group discussion as the main data collecting technique, besides in depth interview and documentation study. Informant for this research are KPU commissioner in period 2009-2014, democracy volunteers, targeted audiences that consist of segment of female community, segment of initial voter community, segment of marginal community, segment of religious community, and segment of disability community.

\section{The Roles of Democratic Volunteers as Facilitators of Politics Education / Community based Voting Education in 2014 General Election}

The Democratic Volunteer Program is initially founded by Comission of General Election pursuant to Surat Edaran (Circulated Letter) No.609/KPU/IX/2013 related to 
strategic policy of civils and formal institution synergy. Therefore, training models for the volunteer is highly required to optimize the potentials of civils as facilitators in various political events, as well as to improve the public faith to democratic process. According to Zamroni (2001) the developing community based political education is expected to change the education objectives which are emphasized on independency, cooperation with others in gaining the shared pluralism based goals.

The democratic volunteers have to be well-prepared in order to increase their capacity as facilitators of political education. The preparation can be a case of improvement of teaching methodologies and the implementation of training evaluation systems. As the facilitators of political education or voters' education, the volunteers have to understand the basic principles of democratic practiced among their community.

The efforts of particular community based on political education like initial voters, female voters, and slums community are still incidental and conducted before the general election is held.Study conducted by Al Rafni and Suryanef (2013) reveals that the political guidance for female party candidates is not comprehensive and systematic. It is only conducted by a particular party in some particular events before the general election. While Suryanef and Fatmariza H. (2014) describes that the voters' education for initial voters are conducted by the General Commission Election, political parties and community organization. Political education facilitated by the democratic volunteers requires early preparation through wellplanned and comprehensive training models investigation. The political education is expected to increase public faith in national political practices.

The failure in political education implementation becomes one of crucial factors of the decrease of public faith toward a party (Muhammad Yahya Arwiyah, 2012). However, the maximum political education given will be in line with the improvement of citizen political literacy. Experts believe that every citizen should have political knowledge as a requirement of a good functioned democracy (Lutz, 2006). The development of democracy involves a lot of parties. Theory of democratic development according to Soedjatmoko, as quoted by Ema Khotimah (2006), implies a requirement of many perspectives.
The program of democratic volunteer that belongs to civic movement is regarded as a phenomenal movement as the democratic facilitators are previously from the government or some particular parties of interests. As agent of transformative political agent, the democratic volunteers are expected to bring massive changes in conducting political education/voter education. Findings of the study reveals that the community tends to rely on their peer information compare to that formal information delivered by the government officials. The reason behind this finding is that the community feels more comfortable to obtain knowledge and information from their peers. Thus, the role of democratic volunteers as agents of political education is considered a big transformation.

The political information transmission process is previously dominated by those who are in restricted formal condition. However, when the democratic volunteers are able to perform their tasks optimally, an active political culture could be achieved. Political education is equally regarded as democratic education. Gandall and Finn (1992) support the notion that democracy does not teach itself. If the strengths, benefits, and responsibilities of democracy are not made clear to citizens, they will be ill-equipped to defend it. It resembles that the democracy has to be exposed to the community through education, so that it could be understood by the citizens. They further propose that education (is) for democracy, and it must be approached in a conscious and serious manner. Thus, the democracy education has to be seriously responded. The education according to Gandall and Finn (1992) seek not only to familiarize people with the precepts and practices of democracy, but also to produce citizens who are principled, independent, inquisitive, and analytic in their outlook. The education does not merely expose the learners or citizen with the knowledge and practice of democracy, but also will produce good quality of democratic citizens.

It is obviously expected that political education facilitated by the democratic volunteers has to be dialogic, critical and actively transformed. The finding of the study also reveals that the political teaching and learning are still mostly conducted through formal way like it is conducted to segment of initial voters. Students' political interest and votes are gained through the school coordination. There is a dialogic process occurring, yet the delivery system 
has not regarded effective. However, the different findings are obtained from other four communities. Those volunteers who are in charged in marginal community, female community, religious community and disable community have conducted informal, dialogic, and active political education strategies. To build critical consciousness, the volunteers are intentionally chosen from the same community to make it easier in disseminating any political information and knowledge through peer learning. Thus, it can be said that the polical education process does not merely involves the cognitive and rational aspects but also the emotional aspects.

The objectives of transformative political education are: (1) promoting the citizens to be more critical and militant; (2) encouraging the community are able to perform the efficient political functions; and (3) giving a contribution to the process of true democracy. It can be concluded that the political education in Indonesia refers to series of systematic and intentional education to develop community political awareness (Kartini Kartono, 2009).

To achieve those objectives, a set of training models have already been designed. According to Lynton and Preek U (1990) training is an effort to prepare trainees in making a decision or particular actions as well as to prepare the trainees to gain their achievement. Training model is the design consisiting of planning and systems of a program (Soebagio, 2002). It is expected that the training is regarded instructional or experiencial in developing an individual's knowledge, behaviour and skills. Good (1982) explains the training model through some cycles, namely: (1)analyze to determine training requirement; (2) design the training approach; (3) develop the training material; (4) conduct the training; and (5) evaluate and update the training.

The needs for training analysis can be obtained through assessment questionnaires, aimed at finding the data of the trainees' need. After the analysis, training model construction will be designed; materials, methodology and other guidances will also be prepared. Material development will be the next step and followed by the implementation. The last step is evaluation consisting of four phases, namely: (1)reaction level; (2) learning level); (3) behavioral level; and (4) result level. According to Blanchard and Thacker (2010) training process model consist of five phases, namely analysis, design, development, implementation and evaluation.

Beside understanding the training program, the facilitators of political education have also to understand the meaning, objectives and methodology of the education. Political education is regarded as a process of influencing individuals to get information, knowledge and political skills, so that he/she possesses the capability to be critical and explicit in making a political decision (Kartini Kartono, 2009).

\section{Democratic Volunteer Work in Devel- oping Citizen's Political Literacy}

The democratic volunteers work on five segments of people: (1) female community; (2) beginners/initial voter community; (3) Marginal community; (4) religious community; and (5) disable community. Their work has been practice of political literacy in the nation. It is not a normative concept but the combination of knowledge, skills and political behaviour (Andi Faisal Bakti, 2012).

Crick as quoted by Andi Faisal Bakti (2012) clarifies that the political literacy is not merely about political knowledge, but also how to be effectively involved in public and actively participating in conducting the civil right and obligation.

The findings of the study related to democratic volunteers in developing community political literacy can be describe as follows:

\section{Segment of Female Community}

The volunteers give particular treatment in facilitating the female community. They usually deliver the information in traditional woman social club (arisan). Another way conducted is by giving the woman an awareness of how important and big the political chances given to women that they could effectively participated in political practices.

Generally, there are four pivotal arguments that makes the importances of women involvement in politics, namely: work or roles related to women, equality, women interests, and democracy revitalisation (Squires, 2000).

Further, Squires (2000) in his book of Gender in Political Theory mentioned that special treatment are required for women. $\mathrm{He}$ also explains that women will be placed in different position in their community to 
struggle for their own right and needs as well as their particular interests.

The inequality occurring to women in political aspects requires intensive effort as described by Andi Faisal Bakti (2012): First, women have to be able to ruin the gender bias, Second, women have to be empowered, Third, Women have to possess good quality networking, Fourth, women have to improve their political ability and skills.

Further discussion is held related to the causes of gender inequity in political aspects, namely: (1) unfair political system; (2) socio cultural issues; (3) psychological problems; and (4) socio economic issues. Related to unfair political system, there are five issues found in political system which limits women participation in politics, namely: (1) masculine model in any political life, government bodie,s and institution. Men are politically dominated; they formulate the political regulations and determine the standard of evaluation. Political life is arranged by male norms and values. The political model is determined through competition and confrontation. The masculine political principles do not involves respects, collaboration and concensus; (2) lack of political party support, small amount of fund for female candidates in campaigning, limited access of networking, and double standard for women. The selection process is also gender bias compared to males; (3) weak cooperation and collaboration among women organization; (4) the availability of training system and education for women leaders are almost null; and (5) the question of whether the essence of the election is beneficial for women or not.

Issues on social and culture becomes pivotal. It is regarded that males have more access and powerful position in public sphere, while women are jailed in limited condition like domestic sphere. Such conception has been sadly applied in any community in the world.

Psychologically, women are mostly having a low self-esteem compared to male partners. They tend to be weak and scared when a conflict occurs, whether the conflict is mental or physical abuse. The implication is that women tend to be reluctant in taking prominent roles in politics or in political parties. Besides, the basic character of women is more emotional than men. Moreover, women also give high priority on a relationship and other people. It obviously becomes an obstacle for them to have perfect career in politic or political party. Further, women are more dilemmatic in deciding or solving a conflict. Socio economic issues which become the problem for women to actively participate in politic can be described as: (1) poverty and unemployment (2) possessing weak monetary sources; (3) illiterate and low access to education; and (4) double obligation between domestic work and social obligation.

Of those obstacles, according to the democracy volunteers, the dominant factors which avoid women from politics are psychological and socio economic. The reluctance of women to be politically involved is regarded as psychological issues. Most women do not working and financially dependent on their husbands.

\section{Segment of Initial Voter Community}

The initial voters are defined as those who are firstly possessing their right to vote. They are regarded potential market for the candidates for five reasons, namely: (1) they are unstable; (2) their political knowledge is relatively low; (3) they are peer-group dominated; (4) they vote based on the popularity aspects of a candidate or political party; (5) they come to the Voting Site to register or unregister their voting right (Andi Faisal Bakri, dkk., 2012). Thus, pursuant to the prior description, it can be comprehended that the initial voters highly need a comprehensive political education.

Further, Pomper (1975), states that the intial voters possess their own particular political behavior. A study related to voting behavior in the United States shows that the initial voters are much more interested in political issues rather than political actions. Their potentials are dualistic. In one side, it is positive and it is negative in another side. The profile of initial voters is based on obtained political socialization process. The socialization is regarded as a process in which an individual passively agree on values, attitudes, roles in the community as well as active in developing their independence.

The democratic volunteers conduct some efforts in developing political literacy of the initial voters, such as visiting schools and universities as well as cooperating with youth organizations which enable them to socialize all things related to the general election and make initial voters a rationale one. The rational voters have the ability to consider any options since they possess motivations, knowledge principles, and sufficient information. Their political action 
is not accidentally and habitually performed, but they realize that their votes are beneficial for public interests.

The characteristics of rational voters are as follows: (1) they are able to make a quick decision when they are facing alternatives; (2) they are able to compare whether the alternatives are preferred or ordinary; (3) they are able to arrange alternative transitively; (4) they are able to determine the higher level of preferences; and (5) they are able to be consistent in making a decision when they face the similar alternatives (Efriza, 2012).

\section{Segment of Marginal Community}

The marginal community might be forgotten when a massive decision related to their live is voted. The finding reveals that the democratic volunteers have aided this community to understand politics, to access the political information, and to communicate their political needs as well as to evaluate the political process. Consequently, the marginal community could be the political subject instead of political object misguided by a particular party. Some political literacy activities offered peer group sharing to this community and also empowering some political education process. The activities are usually conducted after they have finished their works.

\section{Segment of Religious Community}

The improvement of citizen political literacy in segment of religious community is pursuant to the perspective that all religions in Indonesia teach universal values like, justice, honesty, peace, tolerance and consensus as well as the independency. The values are equal to those practiced in the citizens' life. The synergy of the religious values will be significant for political literacy improvement. The political education facilitators should be the inspiration of the community. It is revealed that the volunteers are able to educate interreligious community. They conduct the political literacy activity in mosques, churches or temples.

\section{Segment of Disability Community}

The disability persons (persons with disabilities or PD) have their own right to get the political socialization. The statement has been supported by the Regulation No. 4 Year 1997 and the Government Regulation No. 43 Year 1998 stating that they are equally treated. Thus, government provides the political accessibility for them to conduct their own political right.

The accessibility needs of the disable (PD) have to be fulfilled in every general election conducted. The right is also voiced and protected by Convention on the Right of Persons with Disabilities (CRPD). The convention guarantees that the disables are completely able to participate in politics. They have the right to vote and to be voted. Thus, the democratic volunteers will conduct the socialization of general election by visiting the disabled residence. Further, the volunteer will facilitate a dialogue related to process and Indonesia political dynamics, particularly related to the general election process. The simulation will be held for the next steps by using some facilitates for the disables.

From the study, it is revealed that there are many disable who do not realize the importance of their political participation. Only a few of them know the procedures of voting. In addition, the voting sites are mostly inaccessible for the difables. According to the democratic volunteers, there are three significant informations delivered to the community, namely that: (1) they have an equal political right; (2) they have to know the tools and the infrastructure of the accessible voting sites; and (3) the inclusive of general election implementation.

\section{Conclusions}

Political literacy is not merely related to political knowledge, but also a way "to make a person act effectively in political life". Democratic volunteers as facilitators of political education are expected to perform their roles as transformative political education agents. One of the roles is to facilitate the change of indoctrine learning strategies to critical, dialogic, and participative learning strategies.

As facilitators of transformative political education, the volunteers deliver the materials of political education through an exclusive strategy pursuant to the targeted community. The political education is also built in based on community political consciousness and facilitated by the community themselves. The materials, strategy and media are selected based on the targeted community.

\section{References}

Affandi, I. (2009). Bedah Buku Political Education dari Robert Brownhill dan Patricia Smart. Bandung: Sekolah 
Pascasarjana UPI.

Al Rafni and Suryanef. (2013). Pengembangan Model Pembinaan Perempuan Kader Partai oleh Partai Politik sebagai Upaya Peningkatan Kualitas Kerwakilan Perempuan di Lembaga Legislatif Daerah. Laporan Penelitian Hibah Bersaing Lembaga Penelitian Universitas Negeri Padang.

Arwiyah, M. Y. (2012). "Status Sosial Ekonomi dan Kualitas Partai Politik dalam Meningkatkan Partisipasi Politik" dalam Jurnal Mimbar, Vol. XXVIII, No.1 Juni 2012 halaman 85-92. Terakreditasi SK Dikti No.64a/DIKTI/Kep/2010.

Atmodiwiro, S. (2002). Manajemen Pelatihan. Jakarta : PT. Ardadizya.

Bakti, A.F. (Editor). (2012). Literasi Politik dan Konsolidasi Demokrasi. Jakarta : Churia Press.

Blanchard, Nick P. ; Thacker, James W. (2010). Effective Training : System, Strategies, and Practices. New Jersey : Pearson.

Efriza (2012). Political Explore: Sebuah Kajian IImu Politik. Bandung: Alfabeta.

Gandal, J.E. \& Finn, E.S. (1992). Education for Democracy. Calabasas : CCE.

Good, T. W. (1982). Delivering Effective Training. California: University Ase.

H.A.R. Tilaar. (2000). Perubahan Sosial dan Pendidikan: Pengantar Pedagogik Transformatif Untuk Indonesia. Jakarta: Grasindo.

Kartono, K. (2009). Pendidikan Politik Bagian Dari Pendidikan Orang Dewasa. Bandung: Mandar Maju.

Khotimah, E. (2006). "Pembangunan dalam Perspektif Ekofeminisme (Analisis Kritis Paradigma Teori Pembangunan dan Urgensi Pembangunan Perspektif Demokratis
Kulturis dalam Upaya Meningkatkan Indeks Pembangunan Manusia)" dalam Jurnal Mimbar, Vol. XXII, No.3 JuliSeptember 2006 halaman 333-354. Terakreditasi SK Dikti No.23a/DIKTI/ Kep/2004 tanggal 4 Juni 2004.

Lutz, G. (2006). Participation, Information, and Democracy. Rutger University.

Lynton, R. P. \& Preek U. (1990). Training for Development. West-Hartford: Kumarian Press.

Pembangy, M. (2008). Pendidikan Transformatif: Pergulatan Kritis merumuskan Pendidikan Ditengah Pusaran Globalisasi. Yogyakarta: Teras.

Ravitch, D. (2010). The Death and Life of the Great American School System : How Testing and Choice are Undermining Education. New York: Basic Book.

Sunarso. (2007). "PendidikanPolitik dan Politik Pendidikan" dalam Jurnal CIVICS Vol.4 No.2, Desember2007. Yogyakarta : Jurusan PKn dan Hukum FISE Universitas Negeri Yogyakarta.

Sirimorok, N. (2010). Membangun Kesadaran Kritis: Kisah Pembelajaran Partisipatif Orang Muda.

Suryanef and Fatmariza H. (2014). Pengembangan Model Pendidikan Pemilih (Voter Education) Dalam Rangka Membangun Rasionalisasi Perilaku Memilih Pemilih Pemula dalam Pemilu di Kota Padang.Laporan Penelitian Hibah Bersaing - Lembaga Penelitian Universitas Negeri Padang.

Squires, J. (2000). Gender in Political Theory. Cambridge : Polity Press.

Zamroni. (2011). Pendidikan Demokrasi Pada Masyarakat Multikultural. Yogyakarta: Gavin Kalam Utama. 